\title{
Menkes disease: recent advances and new aspects
}

\author{
Zeynep Tümer, Nina Horn
}

Copper is the third most abundant trace element in the body, after iron and zinc, and it is required for the normal function of several important copper enzymes. However, the same element in excess is highly toxic and has detrimental effects. Fine regulation of intracellular copper homeostasis is therefore vitally important and disturbance of this balance is reflected in two hereditary disorders, Menkes disease and Wilson disease. In recent years, remarkable progress has been made in this field following the isolation of the defective gene in Menkes disease (MD), which will be the main focus of this review.

Progressive neurodegeneration and connective tissue disturbances are the main manifestations of $\mathrm{X}$ linked recessive Menkes disease and most of the clinical features can be explained by malfunction of one or more copper enzymes. The disease locus has been mapped to $\mathrm{Xq13.3}$ and the gene (MNK) defective in Menkes disease has been isolated by positional cloning. The protein product is predicted to be a copper binding $P$ type ATPase (ATP7A), the first intracellular copper transporter described in eukaryotes. Identification of MNK led to a series of advances in a very short time. The mouse homologue of MNK has been isolated and the allelic relationship between MD and the occipital horn syndrome confirmed. Most importantly, the gene defective in Wilson disease was isolated using sequences specific to MNK and the predicted protein product showed high homology to ATP7A. In this review we will outline these recent advances and their consequences with special reference to Menkes disease. Wilson disease will be described briefly, and the defective copper metabolism in both diseases will be summarised in the light of the new insights. Finally, copper translocating ATPases identified in other species and their significance in understanding copper metabolism will be discussed. (F Med Genet 1997;34:265-274)

The John F Kennedy Institute, G1 Landevej

7, 2600 Glostrup,

Denmark

Z Tümer

N Horn

Correspondence to:

Dr Tümer, Department of

Medical Genetics, Panum

Institute, University of

Copenhagen, Blegdamsvej,

2200 Copenhagen,

Denmark.
Menkes disease (MD) is a multisystemic letha disorder, dominated by neurodegenerative symptoms and connective tissue manifestations. ${ }^{1-3} \mathrm{~A}$ striking and pathognomonic feature is the sparse, coarse, and depigmented
Table 1 Main symptoms of patients with the classical form of Menkes disease and OHS

\begin{tabular}{lll}
\hline & $M D$ & OHS \\
\hline Neurological symptoms & & \\
$\quad$ Mental retardation & ++ & $+/$ \\
Convulsions & ++ & - \\
Hypothermia & + & + \\
Feeding difficulties & + & + \\
$\quad$ Muscle tone changes & + & $\mathrm{ND}$ \\
Connective tissue symptoms & + & + \\
$\quad$ Tortuous vessels & + & ++ \\
Skeletal changes & + & ++ \\
Bladder diverticulae & + & + \\
Loose skin & + & + \\
Loose joints & & + \\
Other symptoms & + & + \\
$\quad$ Facial dysmorphism & + & $\downarrow$ \\
Abnormal hair, pili torti & + & + \\
Hypopigmentation & & + \\
Laboratory findings & $\downarrow \downarrow$ & \\
Serum copper & $\downarrow \downarrow$ & \\
Serum ceruloplasmin & + & \\
Intracellular Cu accumulation & Death before & $\star$ \\
Life span & 3 years &
\end{tabular}

*Except for four patients, all the known OHS patients (about 22) are still alive, the oldest patient being 52 years old. Two patients have died in car accidents (I Kaitila and P Byers, personal communication), one patient has died of an unknown cause at 40 years of age (I Kaitila, personal communication), and one patient has died aged 49 years because of a bladder rupture (D Weaver, personal communication).

ND, not determined.

hair, the reason why the disease has also been called "kinky or steely hair disease" (fig 1). Though most patients (90-95\%) have a severe clinical course (table 1), various forms of the disease exhibiting different degrees of nervous system or connective tissue involvement can be distinguished. ${ }^{4}$ The occipital horn syndrome (OHS), mainly characterised by connective tissue manifestations, has been suggested to be a very mild allelic form of $\mathrm{MD}^{5}$ (table 1 ). Besides OHS, a late onset mild form ${ }^{67}$ and a moderate form can also be distinguished from the severe classical form. ${ }^{4}$ Variation also exists within these groups and there are, for example, a significant number of patients surviving more than six years despite the severe clinical symptoms. ${ }^{4}$ It is thus conceivable that MD covers a clinical continuum from the severe classical form to the mild OHS. ${ }^{4}$

Involvement of copper metabolism in $\mathrm{MD}$ was first described by Danks et al, ${ }^{8}$ showing low serum levels and defective intestinal absorption of the metal. At first, copper malabsorption was thought to be the primary cause, but later investigations showing copper accumulation in extrahepatic tissues, apart from the brain, indicated a multisystemic involvement. ${ }^{910}$ Most of 


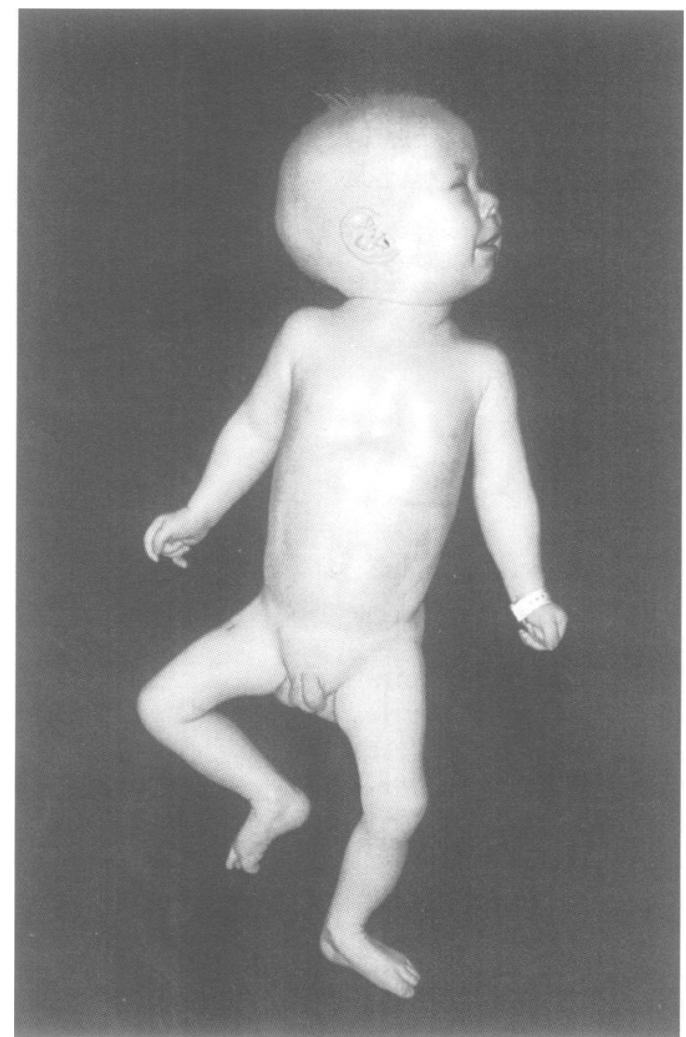

Figure 1 A 9 month old Menkes disease patient with the severe lethal form. (Photograph reproduced with permission.)

the clinical features of MD are attributable to deficiency of one or more important copper requiring enzymes, such as cytochrome c oxidase (electron transport), superoxide dismutase (free radical detoxication), dopamine $\beta$ hydroxylase (catecholamine production), lysyl oxidase (cross linking of collagen and elastin), and peptidyl-glycine $\alpha$-amidating monooxygenase (PAM, bioactivation of peptide hormones).

\section{Genetics of Menkes disease}

LOCALISATION OF THE MENKES LOCUS

Menkes disease was recognised to segregate as an $\mathrm{X}$ linked recessive trait when it was first described in 1962 by Menkes et al. ${ }^{1}$ Cell culture studies in phenotypically normal female Menkes carriers indicated that the Menkes disease gene (MNK) was subject to random $\mathrm{X}$ inactivation, also supporting an $\mathrm{X}$ linked mode of inheritance. ${ }^{11}$ Later, MNK was linked to the centromeric region of the $\mathrm{X}$ chromosome by $\mathrm{C}$ banding polymorphism studies ${ }^{12}$ and further linkage analyses, exclusion mapping, and comparative gene mapping between man and mouse suggested proximal $\mathrm{Xq}$ as the candidate region. ${ }^{13-17}$

The first physical evidence for the location of MNK was the finding of a female Menkes patient with a balanced X;2 translocation ${ }^{18}$ and the $\mathrm{X}$ chromosome breakpoint was localised to Xq13.2-q13.3. ${ }^{19}$ This finding suggested that the $\mathrm{X}$ chromosome breakpoint was at or very near the Menkes locus, directly affecting the function of the gene. Description of another Menkes patient with an X chromosome abnormality involving Xq13 not only supported this region as the candidate locus for $\mathrm{MNK}$, but also finely localised it to $\mathrm{Xq} 13.3 .^{20}$ This patient was a male carrying a unique intrachromosomal rearrangement where the segment $\mathrm{Xq13}$ 3-q21.2 was inserted into the short arm. $^{2021}$

ISOLATION OF THE GENE DEFECTIVE IN MENKES DISEASE

The finding of two Menkes patients with $\mathrm{X}$ chromosome breakpoints within the candidate region expedited the efforts in cloning MNK. Three groups, including ours, isolated MNK using slightly different positional cloning strategies. ${ }^{22-24}$ The $\mathrm{X}$ chromosome breakpoint of the $\mathrm{X} ; 2$ translocation patient was the starting point for all three groups, though our group also investigated the patient with the intrachromosomal rearrangement. ${ }^{20}$ The common step was to construct a physical map of the genomic region encompassing the site of the breakpoints and to isolate YACs (yeast artificial chromosomes) covering this region. ${ }^{22-25}$ Screening cDNA libraries with different kinds of probes enabled all three groups to isolate candidate cDNA sequences which were mapping to the breakpoint region and were identical to each other. ${ }^{22-24}$ Southern blot analysis of 16 unrelated Menkes patients referred to our institute showed partial gene deletions of different sizes and locations, indicating that this candidate gene was defective in $\mathrm{MD}$, and hence was "the" Menkes disease gene (MNK). ${ }^{23}$ Furthermore, in line with the disturbed copper metabolism the predicted protein sequence showed a P type ATPase with striking sequence homology to a bacterial heavy metal binding protein. ${ }^{22}$ The predicted protein is now designated ATP7A and the $\mathrm{MNK}$ gene is occasionally called ATP7A.

The mRNA transcript of MNK is $8.5 \mathrm{~kb}$ long and the $3^{\prime}$ end contains a $3.8 \mathrm{~kb}$ untranslated region. ${ }^{22}$ An open reading frame of 4500 $\mathrm{bp}$ is identified encoding a predicted protein of 1500 amino acids. The mRNA transcript is expressed in heart, brain, lung, liver, skeletal muscle, kidney, and placenta, but the level is low in pancreas and hardly detectable in liver $\mathrm{MNK}$ is organised in 23 exons spanning about a $150 \mathrm{~kb}$ genomic region ${ }^{26}$ (fig 2). The first exon is a leader exon containing only untranslated sequences and the ATG start codon is in the second exon. The exons in general correspond to the predicted functional structural domains of the protein product with a few exceptions. ${ }^{26}$

\section{About the protein (ATP7A)}

Comparison of the predicted protein sequence $(\mathrm{ATP} 7 \mathrm{~A})^{22}$ with other sequences in protein databases indicated a close similarity to cation transporting $\mathbf{P}$ type ATPases, especially a heavy metal ion ATPase, involved in copper homeostasis in Enterococcus hirae. ${ }^{27}$ It was also closely related to the cadmium resistance ATPases found in Staphylococcus aureus. ${ }^{28}$

$P$ type ATPases are energy using membrane proteins, functioning as cation pumps either for uptake, efflux, or cation exchange. These enzymes are called "P type" ATPases, because 


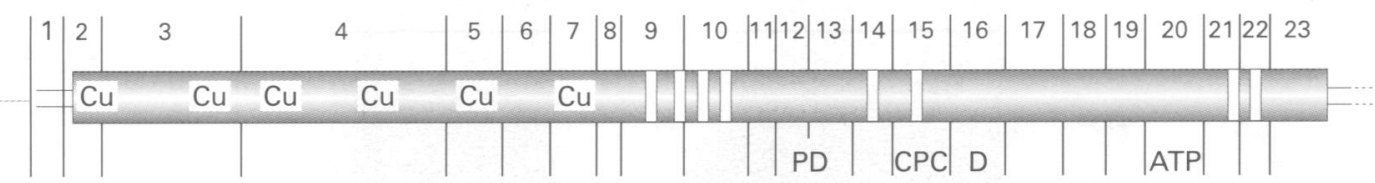

B

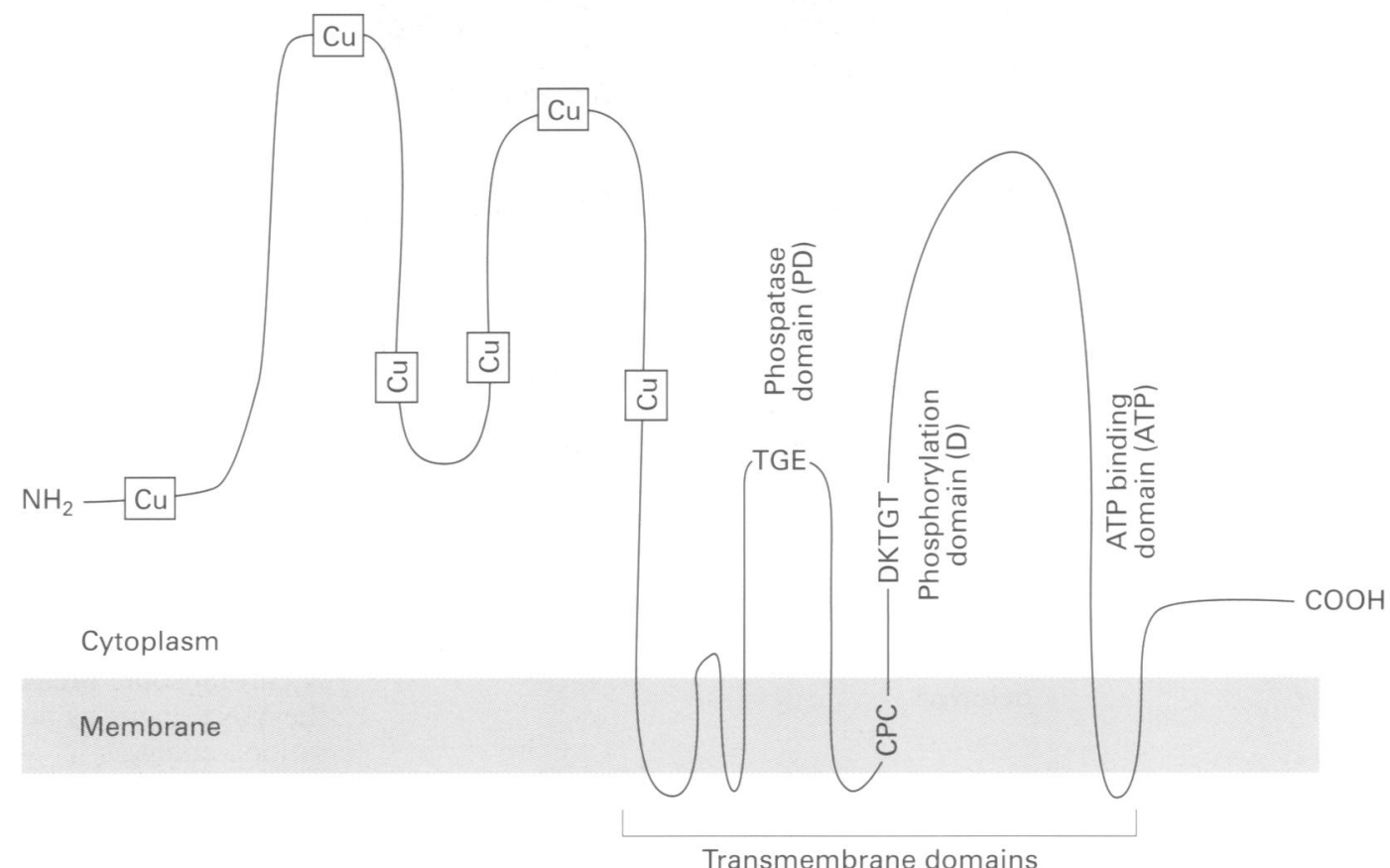

Figure 2 (A) Exon structure of MNK and corresponding protein domains. ${ }^{26}$ The vertical lines indicate the positions of the introns and the exons are indicated by numbers. $(B)$ Predicted protein structure of $A T P 7 A .{ }^{22}{ }_{23}$ The structure of $A T P 7 B$ is also predicted to be similar to ATP7A. ${ }^{87}$ Transmembrane domain is a common structural feature of $P$ type ATPases and anchors the protein into the membrane. ATP7A is predicted to have eight transmembrane domains (indicated with white bars in fig $2 A$ ). ATP binding domain (ATP) is an extramembranous segment, responsible for ATP binding in $P$ type ATPases and it is one of the most conserved sites. Phosphorylation domain (D) contains an invariant cytoplasmic DKTGT motif. The aspartate residue (D) is crucial for the enzyme activity and it is phosphorylated with the terminal phosphate of $A T P$ in the cation transport cycle. CPC is the predicted cation channel with a proline residue $(P)$ highly conserved among $P$ type ATPases. This residue is proposed to participate in the transduction of energy from the phosphorylation site to cation transport. In ATP7A proline is surrounded by cysteine residues, which may provide specificity for heavy metals.

Phosphatase domain (PD) contains the TGE motif, which may have a role in removing the phosphate from the phosphorylated aspartic acid (D) as part of the cation transport. The amino-termini of $P$ type ATPases is one of the most divergent domains. The GMXCXXC motif with a pair of conserved cysteine residues is repeated six times in ATP7A and this motif is suggested to be binding copper $(\mathrm{Cu})$.

of a conserved aspartate residue (D) that is transiently phosphorylated with the terminal phosphate of ATP during the transport of the cations across a membrane. The overall sequence similarity among prokaryotic and eukaryotic cation transporting ATPases suggest that these proteins have been modified throughout evolution in response to the need for translocation of various cations. ATP7A has all the features common to $P$ type ATPases $^{22}{ }^{29-33}$ (fig 2B). A remarkable feature of this protein is the presence of six successive repeats at the amino terminal. These repeats contain the consensus GMXCXXC motif and the presence of paired cysteine residues suggests that these domains are the copper binding sites.

\section{The mottled mouse}

Soon after the isolation of MNK the status of mottled mouse, which was long thought to be the murine model for Menkes disease, was established. In mouse, 23 known mutations ( $Y$ Boyd, personal communication) at the same $\mathrm{X}$ linked mottled locus ( $M o$ ) lead to a mottled coat pigmentation in the female heterozygotes and the affected males show neurological and connective tissue abnormalities, differing greatly in severity. ${ }^{34}$ Phenotypic and biochemical similarities between MD patients and mottled mutants, ${ }^{35-37}$ along with the conserved map positions of $\mathrm{MNK}$ and $M o,{ }^{15}{ }^{16}{ }^{38}$ have long suggested that $M o$ phenotypes were caused by mutations in $M n k$, the mouse homologue of MNK. Following the isolation of MNK, Mnk 


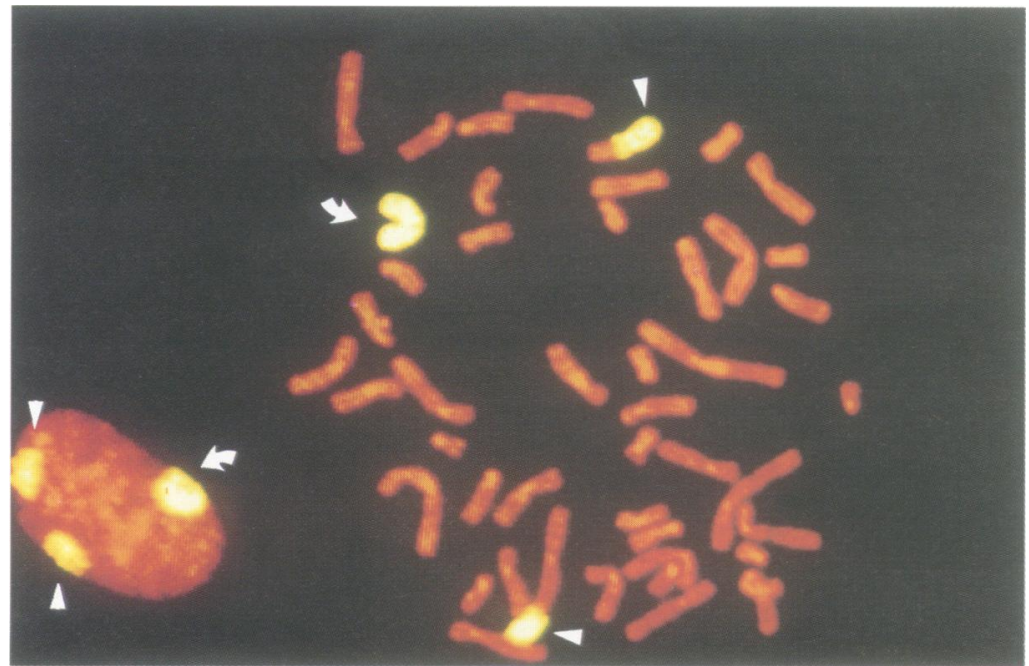

Figure 3 Chromosome painting of the metaphase and interphase chromosomes of the female Menkes patient with $X ; 2$ translocation, using hamster cell hybrid containing a single human X chromosome (CL-20, kindly provided by $T$ Kruse). The normal X chromosome is indicated with an arrow and the derivative chromosomes with arrow heads. (The photograph was taken by $\mathcal{\exists}$ Hindkjar on a confocal laser microscope.)

was cloned using the human sequences. ${ }^{39} 40$ The predicted protein product was also a $\mathrm{P}$ type ATPase (atp7a), showing $89 \%$ sequence homology to ATP7A, and the tissue expression profile was also similar to the human counterpart. In the two mottled mutants, mottled blotchy $\left(M o^{b l o}\right)$ and mottled dappled $\left(M o^{d p}\right)$, altered levels of the $M n k$ transcript were detected. ${ }^{39}{ }^{40}$ Recently a mutation in $M n k$ was reported in $M o^{b l o}$ confirming the status of the Mo mouse as an animal model for $\mathrm{MD}^{41}$ (see below).

\section{The occipital horn syndrome}

Cloning of MNK provided the opportunity to analyse the occipital horn syndrome (OHS) patients for an allelic mutation. These two $\mathrm{X}$ linked recessive disorders of copper metabolism, were suggested to be allelic based on their biochemical and clinical resemblances (table 1), and their homology with the possibly allelic forms of the mottled mouse. Two well characterised mottled mutants, the mottled brindled $\left(M o^{b r}\right)$ and the mottled blotchy $\left(M o^{b l o}\right)$, were suggested as the murine models for the classical form of $\mathrm{MD}$ and OHS, respectively. The $M o^{b r}$ phenotype and classical MD have similarly disturbed copper homeostasis leading to severe neurological impairment and death at an early age. ${ }^{35}$ The $M o^{b l o}$ phenotype resembles OHS showing predominantly connective tissue manifestations.$^{36}$ Both in MD and OHS, serum copper and ceruloplasmin are low, though usually lower in $\mathrm{MD}$ and occasionally normal in OHS. ${ }^{42}$ Cultured fibroblasts of OHS and MD patients show increased copper accumulation and markedly low lysyl oxidase activity. ${ }^{53}$ In OHS the major effect is on lysyl oxidase, the copper dependent enzyme that initiates cross linking of collagen and elastin in connective tissues. However, the possibility of a primary defect in the lysyl oxidase gene was excluded by the assignment of the gene to an autosome. ${ }^{44}$

Following the isolation of MNK, Levinson $e t$ $a l^{45}$ detected markedly reduced levels of the mRNA transcript in two unrelated OHS patients, suggesting that $\mathrm{MNK}$ had a role in OHS. Recently, impairment of MNK in three patients with OHS has been reported, giving direct molecular evidence for the allelic relationship between these two diseases ${ }^{4146}$ (unpublished data). These mutations are base pair substitutions affecting the normal mRNA splicing and the $M o^{b l o}$ also has a similar splicing defect. ${ }^{41}$ Further studies, elucidating the effects of the gene mutations on the structure and function of the protein, are required to understand the cellular pathology resulting in different phenotypes in mice and humans.

\section{Females with Menkes disease}

A total of eight females affected with Menkes disease have been described (Tsukahara, personal communication). ${ }^{18}{ }^{47-52}$ In two patients ${ }^{478}$ diagnosis was suggested clinically, and cytogenetic and biochemical analyses were not performed. In three cases, ${ }^{49-51}$ diagnosis was confirmed by significantly increased copper accumulation in cultured fibroblasts. ${ }^{51}$ Two of these patients ${ }^{50}{ }^{51}$ had normal karyotypes and the most likely explanation for the expression of the disease was odd $\mathrm{X}$ inactivation. The third patient ${ }^{49}$ had a $46, X X / 45, X(31.5 \%)$ mosaicism in cultured fibroblasts and expression of the disease could be explained by monosomy of the $\mathrm{X}$ chromosome harbouring the defective gene or by odd $X$ inactivation. ${ }^{51}$ Three female patients had balanced translocations, $t(X ; 2)^{18}$ (fig 3), $t(X ; 1),{ }^{52}$ and $t(X ; 21)$ (Tsukahara, personal communication) and in each case the $\mathrm{X}$ chromosome breakpoint was shown to be at the MNK locus by fluorescence in situ hybridisation analyses ${ }^{25} 52$ (unpublished data). As expected, the normal $\mathrm{X}$ chromosomes were preferentially inactivated in these patients, resulting in the expression of the disease, which was also confirmed by copper uptake studies $^{1852}$ (unpublished data).

\section{Mutation spectrum in Menkes disease}

Menkes disease is one of the so called "new mutation disorders". These are usually $\mathrm{X}$ linked diseases, which are prone to new mutations, and almost every affected family shows a different alteration. ${ }^{53}$ Results to date indicate that the mutations leading to $M D$ show a wide variety from cytogenetic abnormalities to single base pair changes.

Cytogenetically visible chromosome abnormalities comprise about $1 \%$ of the underlying genetic defect in MD. Three of these patients are females with balanced X;autosomal translocations as described above (fig 3). The only male patient with a cytogenetic aberration ${ }^{20}$ was detected during a systematic screening of 180 unrelated Menkes disease patients. ${ }^{21}$ We have recently localised the Xq13.3 breakpoint of the male patient and one of the female patients $^{52}$ within MNK using Southern blot hybridisation (unpublished data).

In about $15-20 \%$ of patients the mutations are gross deletions or rearrangements. With Southern blot analysis we have identified rearrangements or partial gene deletions in about 45 unrelated Menkes patients ${ }^{235}$ (unpublished data) (fig 4). The boundaries of 30 partial gene 


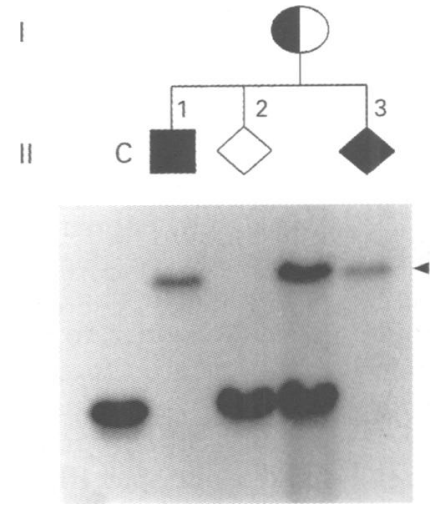

Figure 4 Prenatal diagnosis of $M D$ by Southern blot hybridisation ${ }^{63}$ (reproduced from Tümer et al, $\mathcal{F}$ Med Genet, 1994, with permission). Genomic DNA is digested with the restriction enzyme HindIII and hybridised with a genomic probe including exons 3-5 of MNK. The lower fragment $(10 \mathrm{~kb})$ is the normal band representing the normal $X$ chromosome and it can be observed in the control $(C)$. Index patient II. 1 has only an abnormal band $(23 \mathrm{~kb})$ representing the defective gene. The mother (I) is a carrier of the mutation as indicated by the presence of both the normal and the abnormal fragments. We performed prenatal diagnosis by mutation analysis and the fetus (II.3) had only the abnormal fragment, indicating that he was affected. The biochemical analysis was in line with the $D N A$ results and the family decided to terminate the pregnancy. The male fetus of the mother's previously terminated pregnancy (II.2) shows the normal band pattern, indicating that he was not affected, and exogenous copper contamination had resulted in a false positive biochemical diagnosis. This analysis also shows clearly that chorionic villi (II.2, II.3) were not contaminated by maternal tissue.

deletions were further delimited by PCR amplification of the individual exons with intron specific primers (unpublished data). The deletions show great variability in size and location. The largest defect observed is the deletion of the whole gene except for the first two exons, the leader exon, and the second exon coding for the ATG start codon and the first metal binding domain (fig 2A). The small-
N

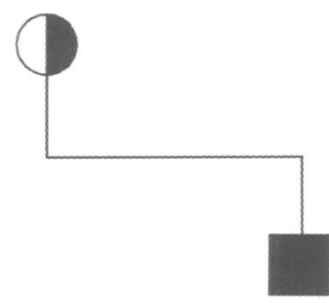

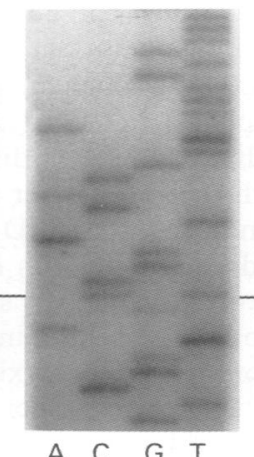

A $C$ G $T$

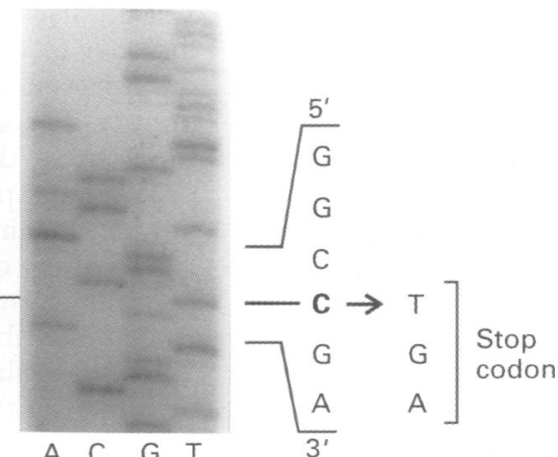

A C G T
A C G T

Figure 5 Carrier diagnosis of $M D$ by SSCP and subsequent direct sequencing using genomic DNA. The index patient has a single base pair substitution (CT) in exon 10 introducing a premature termination codon (R795X) within the fourth putative transmembrane domain. The mother is heterozygous for this mutation and the abnormal $X$ chromosome is preferentially inactivated in line with her normal phenotype (data not shown). The father represents the normal control (N). est mutation shown by this approach is the deletion of the leader exon (unpublished data).

The remaining genetic defects found in MNK are thus base pair changes or very small rearrangements which can be analysed by various PCR based methodologies. Das et a $\tilde{l}^{5}$ have characterised the mutations in 10 patients by RT-PCR (reverse transcription-PCR) and chemical cleavage mismatch detection using RNA. To screen the mutations in our vast patient population, we first determined the genomic organisation of $\mathrm{MNK}^{26}$ and constructed primers to analyse each exon using genomic DNA. Using SSCP analysis (single strand conformation polymorphism) and subsequent direct sequencing of the exons (fig 5) we identified the genetic defect in 41 unrelated patients. ${ }^{56}$ All these point mutations show great variety, including missense and nonsense mutations, deletions and insertions of a single or more base pairs resulting in frameshifts and splice site mutations.

\section{Diagnosis of Menkes disease}

Initial diagnosis of Menkes disease is suggested by the clinical features (especially the typical hair changes) and supported by the reduced levels of serum copper and ceruloplasmin. However, interpretation of these markers may be difficult in the first months of life, as serum copper and ceruloplasmin levels may also be low in normal infants in this period. ${ }^{57} \mathrm{~A}$ definitive biochemical diagnosis exists and is based on the intracellular accumulation of copper owing to impaired efflux. Accumulation is evaluated in cultured cells by measuring radioactive copper $\left({ }^{64} \mathrm{Cu}\right)$ retention after a 20 hour pulse, and impaired efflux is directly determined after a 24 hour pulse chase. ${ }^{58}$ However, these analyses demand expertise and are carried out only in a few specialised centres in the world. ${ }^{2359}$ Postnatal diagnosis is performed on cultured fibroblasts and though a clear discrimination between affected and unaffected males is possible, milder phenotypes cannot be distinguished from the classical form. ${ }^{4}$

Isolation of $\mathrm{MNK}$ and characterisation of the genomic organisation now opens up a new diagnostic possibility, mutation analysis. Demonstration of a defect in MNK will be the ultimate diagnostic proof and as our knowledge about the mutations in the different forms of MD increases, it may also be possible to distinguish the different clinical forms genotypically. However, mutation detection in Menkes disease is quite challenging; the large MNK transcript is organised in 23 exons, the genetic defect shows great variety, and each family has its own unique mutation.

\section{PRENATAL DIAGNOSIS}

Amniocentesis

Prenatal diagnosis of MD was initiated in 1974 by measuring ${ }^{64} \mathrm{Cu}$ accumulation in cultured amniotic fluid cells. ${ }^{60}{ }^{61}$ However, copper accumulation in these cells is less pronounced than in fibroblasts and may occasionally give rise to diagnostic difficulties. Standardisation of the cell culture conditions is therefore crucial and needs expertise. ${ }^{61}$ Amniocentesis should be 
performed before the 18 th week of gestation as the cell growth and hence copper accumulation is negatively correlated to the gestational age.

\section{Chorionic villus sampling}

First trimester prenatal diagnosis is carried out by determining the total copper content in chorionic villi by neutron activation analysis and was initiated in $1983 .^{62}$ As the normal copper content in this tissue is very low ( $1 \mathrm{ng}$ copper per mg tissue), the test is highly susceptible to exogenous copper contamination, which may give false positive results. The whole procedure of chorionic villus sampling must therefore be absolutely free of copper contamination and, as this condition is not always fulfilled, DNA analysis become a valuable supplement. ${ }^{63}$ False positive or negative results in biochemical analysis may also occur when the separation of the maternal tissue from the chorionic villi is not optimal. ${ }^{58}$ Verification of the prenatal diagnosis can be carried out by direct measurement of copper accumulation in the placenta ${ }^{64}$ and this method has also proven to be valuable for neonatal diagnosis of males at risk.

\section{DNA analysis}

DNA based prenatal diagnosis of $M D$ is now possible ${ }^{6365}$ and in some cases may be superior to biochemical diagnosis ${ }^{63}$ (fig 4). However, when the mutation in the family has not yet been identified, biochemical diagnosis will still be preferred as mutation detection in $\mathrm{MD}$ is quite challenging for the reasons mentioned above. Even in the cases where the genetic defect is known, the mutation detection method used has to be optimised before performing the prenatal diagnosis, whereas biochemical diagnosis is already well established. Diagnostic possibilities and risk factors should therefore be evaluated critically for each case.

\section{CARRIER DIAGNOSIS}

Carrier determination by measuring radioactive copper accumulation in cultured fibroblasts is possible. ${ }^{1159}{ }^{66}$ However, owing to random inactivation of one of the $\mathrm{X}$ chromosomes, negative results are not reliable and mutation analyses will therefore provide the ultimate proof of carriership ${ }^{54}$ (figs 4 and 5). Identification of carriers will also have an impact on the number of the prenatal diagnoses referred to our institute, as about $80 \%$ of the male fetuses tested are not affected, indicating that a substantial number of the females are not carriers. Using mutation analyses we have performed carrier diagnosis in about 15 families and in 11 of these families the mother was heterozygous for the mutation found in the index patient (unpublished data).

In families where the mutation is unknown, intragenic polymorphic markers may also enable carrier diagnosis. A $B f a I$ polymorphism has been identified within the coding region of $\mathrm{MNK}^{55}$ and it is localised to exon 10 (unpublished data). Furthermore, two polymorphic CA repeats within the gene (introns 2 and 5) were identified by us and others ${ }^{67}$ and these are currently being used for carrier diag- nosis in the families where the mutation is as yet unknown (unpublished data).

\section{Treatment of Menkes disease}

In MD copper uptake is normal, but a defect in MNK disturbs the intracellular copper homeostasis and copper requiring enzymes cannot receive the copper necessary for their normal function. The objective of a treatment is thus to provide copper to the intracellular compartments where the copper enzymes are synthesised. However, parenteral administration of various copper preparations (as copper sulphate or copper-EDTA) did not produce substantial clinical improvement in MD patients. ${ }^{68}$ On the other hand, copper-histidine, the physiological copper complex found in human serum, ${ }^{69}$ had a positive effect in four unrelated MD patients, who are the oldest surviving patients receiving this therapy. ${ }^{30-73}$ They are now alive between the ages of 7 and 19 years with a milder clinical course resembling OHS. In two of these patients ${ }^{70}{ }^{71}$ we have identified the genetic defect and they both have severe mutations (premature stop codons in exon 4 and exon 12) which would have resulted in a progressive clinical course if untreated. ${ }^{77} \mathrm{How}-$ ever, patients receiving copper-histidine after the first few months of age do not benefit in the same way (though survival may be prolonged), ${ }^{4}$ suggesting that the therapy should be initiated very early, before the occurrence of irreparable neurodegeneration. ${ }^{74-76}$ Studies with the mouse model of MD imply that there is a critical stage in brain development at which copper is essential, suggesting that induced premature delivery of affected infants for early treatment might be beneficial. $^{3}$

In the four patients mentioned above, though the neurological symptoms improved, the connective tissue abnormalities persisted. As lysyl oxidase is the enzyme involved in cross linking of collagen and elastin in connective tissues, these results suggest that the function of this enzyme does not appear to be corrected with copper-histidine administration. However, as indicated by the improvement of the neurological symptoms, copper seems to be delivered to some of the copper requiring enzymes using copper-histidine.

\section{Wilson disease}

Wilson disease (WD) is an autosomal recessive disorder of copper metabolism resulting from the toxic effects of copper, in contrast to $\mathrm{MD}$ mimicking copper deficiency (table 2). Though these two diseases have different clinical progression, the serum copper and ceruloplasmin are low in both cases. WD is mainly characterised by different degrees of liver disease, neurological or psychiatric symptoms, and clinical variability. ${ }^{78} 79$ The clinical features of WD are attributable to the toxic accumulation of copper in the liver and other tissues, such as kidney, brain, and cornea (Kayser-Fleischer rings).

The Wilson disease locus (WND) has been assigned to chromosome $13^{80}$ and was localised within an approximately $1.6 \mathrm{cM}$ region at $13 q 14-21$ by extensive linkage studies. ${ }^{81-83}$ In 
contrast to $\mathrm{MD}$, visible cytogenetic rearrangements, which could lead to straightforward isolation of the gene, were not reported for WD. Identification of MNK encoding a putative copper transporting ATPase, and its hardly detectable expression in liver, led to the suggestion that WD might be caused by a defective liver specific copper transporter. ${ }^{22}$ Soon after, WND was cloned using sequences specific to $\mathrm{MNK}^{84}{ }^{85}$ and to a heavy metal binding site within the amyloid $\beta$ protein precursor. ${ }^{86}$ The $7.5 \mathrm{~kb}$ mRNA transcript is expressed predominantly in liver, kidney, and placenta, while the message is low in heart, brain, lung, muscle, and pancreas. ${ }^{84-86}$ The putative protein product is also a copper binding $P$ type ATPase (designated ATP7B), highly homologous to ATP7A (57\%). ${ }^{87}$ The WNDgene (or ATP7B) has 21 exons in liver transcripts $^{88}$ and 22 exons in kidney transcripts $^{89}$ and its genomic structure shows a remarkable similarity to $\mathrm{MNK}$, organised in 23 exons. $^{26}$

The Long-Evans Cinnamon (LEC) rat showing liver disturbances is suggested to be an animal model for Wilson disease. ${ }^{90}$ The rat homologue of WND has recently been isolated using human specific sequences and it has been shown to be defective in the LEC rat, confirming its status as a murine model for WD. ${ }^{91}$ The predicted protein product of the rat gene is also a copper binding P type ATPase (atp7b) showing $82 \%$ sequence similarity to ATP7B.

Isolation of WND now enables DNA based diagnosis of Wilson disease. Differing from Menkes disease, only point mutations or very small rearrangements are detected in Wilson disease. ${ }^{848689}{ }^{92-94}$ Mutation detection in Wilson disease is also challenging because of the large number of mutations in a $4.1 \mathrm{~kb}$ coding region. However, the presence of haplotypes specific to WND chromosomes may facilitate the mutation analyses as each haplotype is shown to be generally associated with a specific mutation. ${ }^{92}$ Mutation analysis in WD would be of great importance especially in diagnosing potential patients with no family history of Wilson disease and in early diagnosis of the sibs of affected patients.

\section{New insights into normal and defective copper metabolism}

Copper homeostasis depends on a balance between intestinal absorption and biliary excretion. Copper absorbed from the intestine is attached mainly to albumin and transported to the liver, the central organ of copper homeostasis, where storage and biliary excretion of copper and ceruloplasmin synthesis take place. Copper is secreted from the hepatocytes to the plasma bound to ceruloplasmin, but the mechanism by which it is delivered to different tissues is not fully understood. Regulation of intracellular copper homeostasis, from uptake to transport of the metal to its functional destination and export from the cell, is not well known either.

In Menkes disease, as in Wilson disease, serum copper and ceruloplasmin levels are low. In MD intestinal absorption of copper is grossly diminished. ${ }^{8}$ Copper accumulates in intestinal mucosa, kidney, spleen, lung, pancreas, muscle, and skin, while in the liver and brain the copper levels are below normal. ${ }^{9} 10$ The finding of potential $\mathrm{CpG}$ islands has been the first molecular indication that MNK might be a housekeeping gene, required by all or most tissues, in line with the multisystemic character of the disorder. ${ }^{25}$ Consistent with the tissue distribution of copper in Menkes patients, the MNK transcript is also widely expressed. However, two organs, brain and liver, where the copper levels are low, need special attention. The MNK transcript is expressed in brain, supporting the suggestion that in MD low copper levels in this organ might be a secondary effect, owing to diminished transport across the blood-brain barrier. ${ }^{2}$ In liver the MNK transcript is hardly detectable and a straightforward explanation for the involvement of liver in MD awaits further studies.

In MD cellular copper uptake is normal and a defect in MNK causes intracellular accumulation of the metal. Copper enzymes are

Table 2 Comparison of Menkes disease with Wilson disease

\begin{tabular}{lll}
\hline & Menkes disease & Wilson disease \\
\hline Inheritance & X linked recessive & Autosomal recessive \\
Chromosome location & Xq13.3 & $13 q 14.3$ \\
Incidence & $1: 300$ 000 & $1: 100000$ \\
Pathognomonic feature & Kinky hair & Kayser-Fleischer ring \\
Main clinical features & Neurological symptoms & Hepatic disease \\
& Connective tissue symptoms & Neurological dysfunction \\
& Hypopigmentation & \\
Basic pathology & Facial dysmorphism & \\
& Impaired function of copper enzymes & Impaired biliary excretion of Cu \\
Diagnostic markers & Serum Cu $\downarrow$ & Impaired incorporation of Cu into ceruloplasmin \\
& Serum ceruloplasmin $\downarrow$ & Serum Cu $\downarrow$ \\
& Cu accumulation in cultured cells $\uparrow$ & Serum ceruloplasmin $\downarrow$ \\
Prognosis & & Liver Cu $\uparrow$ \\
Animal model & Lethal in severe cases & Urinary Cu excretion $\uparrow$ \\
& Mottled mouse & Effective treatment with chelators \\
Predicted protein & & LEC rats \\
Tissue expression & 1500 AA copper binding ATPase & Toxic milk mice \\
Genomic organisation & All tissues, hardly detectable in liver & Bedlington terriers \\
Gene defect & 23 exons spanning 150 kb genomic region & 1411 AA copper binding ATPase \\
& $1 \%$ cytogenetic abnormalities & Mainly in liver and kidney, low in other tissues \\
& $20 \%$ gross rearrangements & Point mutations or small rearrangements \\
& $80 \%$ small base pair changes & \\
\hline
\end{tabular}


deprived of copper necessary for their normal function, ${ }^{3}$ while the metal is bound to metallothionein, a cysteine rich heavy metal binding protein, which protects the cell from toxic effects of the free ion. It is thus conceivable that ATP7A delivers copper to the enzymes and is also involved in copper efflux. However, copper accumulation is likely to result from a defect in copper translocation across an intracellular compartment, rather than a defective copper export across the plasma membrane. ${ }^{395}$ ATP7A is thus likely to be located in one or more intracellular compartments or organelles, possibly endoplasmic reticulum or golgi apparatus or both, and is involved in the regulation of the intracellular copper pool by translocating the metal through membranes. ${ }^{96}$

In WD it is likely that ATP7B plays a direct role in incorporation of copper into ceruloplasmin and in biliary copper excretion. A defect in WND results in deficient production of ceruloplasmin and copper starts accumulating in the hepatocytes bound to metallothionein. However, in later stages copper accumulation reaches a toxic level and subsequent overflow from liver to other tissues, like brain, cornea, and kidney, leads to a variety of damage to these organs also. Expression of the WND transcript predominantly in liver is in line with the clinical course and the underlying biochemical defect.

$\mathrm{MD}$ is characterised by an overall copper deficiency, while WD is associated with copper toxicity. However, the functions of ATP7A and ATP7B appear to be quite similar. They are both predicted to be copper translocating membrane proteins likely to be located in the intracellular compartments or organelles. ${ }^{9697}$ ATP7A has a role in the delivery of copper to different enzymes, while ATP7B is involved in supplying copper to ceruloplasmin. Furthermore, both proteins are likely to be involved in the excretion of copper from the cell via intracellular compartments or organelles. ${ }^{96}$

Though an important step has been taken by the cloning of the genes defective in Wilson and Menkes diseases, and their murine homologues, the enigma of intracellular copper metabolism is not solved yet. Identification of other potential proteins involved in the copper uptake and intracellular transport will undoubtedly increase our understanding of cellular copper homeostasis.

\section{Copper translocating $P$ type ATPases in other species}

ATP7A shows a remarkable sequence similarity to P type ATPases involved in copper translocation in Enterococcus hirae, ${ }^{27}$ leading to the prediction of the first intracellular copper binding $\mathbf{P}$ type ATPase in eukaryotes. ${ }^{22}$ Since then, a number of related genes have been described in eukaryotes and prokaryotes. These are all predicted to encode $P$ type ATPases with one or more copper binding domains at the amino-terminus. The human members of this copper associated subfamily of the P type ATPases, ATP7A and ATP7B, show high sequence homology. They both have six predicted copper binding domains, including the consensus GMXCXXC motif, and copper binding of one of these domains has recently been reported for ATP7B. ${ }^{98}$ The two other eukaryotic members of this family are the mouse protein atp7a with six copper binding domains $^{39} 40$ and the rat protein atp $7 b$ with five. ${ }^{91}$ Both proteins show remarkable sequence homology to their human counterparts.

In Saccharomyces cerevisiae two genes mapping to different chromosomes were identified and they were predicted to encode for proteins (Pca1 and Ccc2) belonging to this family. ${ }^{99} 100$ Ccc2 contains two copper binding motifs and may provide copper from the cytosol into an extracytosolic compartment. ${ }^{100101}$ This is indeed analogous to the mechanism suggested for ATP7A and ATP7B. ${ }^{96}$ Pcal has a single copper binding motif and may have a role in copper extrusion from the cell. ${ }^{99}$ Among the bacterial members of this family, there are three copper ATPases, Cop A and Cop B described in Enterococcus hirae $e^{27}$ and CtaA described in Synechococcus $7942 .{ }^{102}$ All these proteins are involved in copper homeostasis, where CopA and CtaA are serving in the uptake and CopB in the extrusion of copper, in the respective bacteria. It is likely that not only the eukaryotic cells but most of the prokaryotic cells as well have copper enzymes involved in electron transfer and therefore require copper transport systems. These systems in bacteria and yeast may thus provide an experimentally accessible model for understanding the overall intracellular copper homeostasis in higher eukaryotes. Recently, a role of $\mathrm{Ccc} 2$ in iron metabolism has been described in yeast and it was shown to be providing copper to a ceruloplasmin-like oxidase required for iron uptake. ${ }^{101}$ Identification of other potential copper proteins in bacteria or yeast, and understanding their function, may thus provide insight also into the connection of copper and iron homeostasis in man.

Despite recent advances, copper homeostasis is still not fully understood. However, to solve this enigma we now have the most necessary tools, the animal models, and simple biological systems such as bacteria and yeast.

1 Menkes JH, Alter M, Steigleder G, Weakley DR, Sung JH. A sex-linked recessive disorder with retardation of growth peculiar hair and focal cerebral and cerebellar degenerapeculiar hair and focal cerebra

2 Horn $N$, Tønnesen $T$, Tümer $Z$. Menkes disease: an $\mathrm{X}$-linked neurological disorder of the copper metabolism Brain Pat 1992;2:351-62.

3 Danks DM. Disorders of copper transport. In: Scriver JR Beaudet AL, Sly WS, Valle D, eds. The metabolic basis of inherited disease. New York: McGraw-Hill, 1995:2211-35.

4 Horn N, Tønnesen T, Tümer Z. Clinical variability of the Menkes disease. In: Sarkar B, ed. Metals and genetics. New York: Marcel and Dekker, 1995:285-303.

5 Peltonen L, Kuivaniemi H, Palotie A, Horn N, Kaitila I, Kivirikko KI. Alterations in copper and collagen metabolism in the Menkes syndrome and a new subtype of the Ehlers-Danlos syndrome. Biochemistry 1983;22:6156-63.

6 Procopis P, Camakaris J, Danks DM. A mild form of Menkes' syndrome. $\mathcal{F}$ Pediatr 1981;98:97-9.

7 Danks DM. The mild form of Menkes disease: progres report on the original case. Am $\mathcal{F}$ Med Genet 1988;30:859 64 .

8 Danks DM, Stevens BJ, Campbell PE, et al. Menkes' kinkyhair syndrome. Lancet 1972; i:1100-2.

9 Heydorn K, Damsgaard E, Horn N, et al. Extra-hepatic Heydorn K, Damsgaard E, Horn N, et al. Extra-hepatic
storage of copper. A male foetus suspected of Menkes'disstorage of copper. A male foetus susp
ease. Humangenetik 1975;29:171-5.

10 Horn N, Heydorn K, Damsgaard E, Tygstrup I, Vestermark $\mathrm{S}$. Is Menkes syndrome a copper storage disorder? Clin Genet 1978;14:186-7. 
11 Horn N, Mooy P, McGuire VM. Menkes X linked disease: two clonal cell populations in heterozygotes. $\mathcal{F}$ Med Genet 1980;17:262-6.

12 Horn N, Stene J, Møllekaer AM, Friedrich U. Linkage studies in Menkes' disease. The Xg blood group system and C-banding of the X chromosome. Ann Hum Genet 1984;48:161-72

13 Wieacker P, Horn N, Pearson P, Wienker TF, McKay E, Ropers HH. Menkes kinky hair disease: a search for closely linked restriction fragment length polymorphysim. Hum Genet 1983;64:139-42.

14 Yang HM, Lund T, Niebuhr E, Nørby S, Schwartz M, Shen L. Exclusion mapping of $12 \mathrm{X}$-linked disease loci and 10 DNA probes from the long arm of the X-chromosome. Clin Genet 1990;38:94-104.

15 Davisson M. X-linked genetic homologies between mouse and man. Genomics 1987;1:213-27.

16 Brockdorff N, Kay G, Smith S, et al. High-density molecular map of the central span of the mouse X chromosome. lar map of the central sp.

17 Tønnesen T, Petterson A, Kruse TA, Gerdes AM, Horn N. Multipoint linkage analysis in Menkes disease. Am 7 Hum Genet 1992;50:1012-17.

18 Kapur S, Higgins JV, Delp K, Rogers B. Menkes syndrome in a girl with X-autosome translocation. Am f Med Gene 1987;26:503-10.

19 Verga V, Hall BK, Wang S, Johnson S, Higgins JV, Glover TW. Localization of the translocation breakpoint in female with Menkes syndrome to Xq13.2-q13.3 proximal to PGK-1. Am ₹ Hum Genet 1991;48:1133-8.

20 Tümer Z, Tommerup N, Tønnesen T, Kreuder J, Craig IW, Horn N. Mapping of the Menkes locus to Xq13.3 distal to the $\mathrm{X}$-inactivation center by an intrachromosomal insertion of the segment Xq13.3-q21.2. Hum Genet 1992;88:668-72.

21 Tommerup N, Tümer Z, Tønnesen T, Horn N. A cytogenetic survey in Menkes disease: implications of chromosomal rearrangements in X-linked disorders. $f \mathrm{Med}$ Genet 1993;30:314-15.

22 Vulpe C, Levinson B, Whitney S, Packman S, Gitschier J. Isolation of a candidate gene for Menkes disease and evidence that it encodes a copper-transporting ATPase. Nat Genet 1993;3:7-13.

23 Chelly J, Tümer Z, Tonnesen $\mathrm{T}$, et al. Isolation of candidate gene for Menkes disease that encodes a potentia heavy metal binding protein. Nat Genet 1993;3:14-19.

24 Mercer JFB, Livingston J, Hall B, et al. Isolation of a partial candidate gene for Menkes disease by positional cloning. Nat Genet 1993;3:20-5.

25 Tümer Z, Chelly J, Tommerup N, et al. Characterization of a $1.0 \mathrm{Mb}$ YAC contig spanning two chromosome breakpoints related to Menkes disease. Hum Mol Genet 1992;1:483-9.

26 Tümer Z, Vural B, Tønnesen T, Chelly J, Monaco AP, Horn N. Characterization of the exon structure of the Menkes N. Characterization of the exon structure of the Menkes
disease gene using Vectorette PCR. Genomics 1995;26:43742 .

27 Odermatt A, Suter H, Krapf R, Solioz M. Primary structure of two P-type ATPases involved in copper homeostasis in Enterococcus hirae. F Biol Chem 1993;268:12775-9.

28 Silver S, Nucifora G, Phung LT. Human Menkes $\mathrm{X}$-chromosome disease and the staphylococcal cadmiumresistance ATPase: a remarkable similarity in protein sequences. Mol Microbiol 1993;10:7-12.

29 Pedersen PL, Carafoli E. Ion motive ATPases. I. Ubiquity, properties, and significance to cell function. Trends Biol Sci 1987;12:146-50.

30 Serrano R. Structure and function of proton translocating ATPase in plasma membranes of plants and fungi. Biochim Biophys Acta 1988;947:1-28

31 Vilsen B, Andersen JP, Clarke DM, MacLennan DH. Functional consequences of proline mutations in the cytoplastional consequences of proline mutations in the cytoplas-
mic transmembrane sectors of the $\mathrm{Ca}^{2+}$-ATPase of mic transmembrane sectors of the Ca-

32 Inesi G, Kirtley MR. Structural features of cation transport ATPases. F Bioenerg Biomem 1992;24:271-83.

33 Vulpe C, Levinson B, Whitney S, Packman S, Gitschier J. Isolation of a candidate gene for Menkes disease and evidence that it encodes a copper-transporting ATPase (correction). Nat Genet 1993;3:273.

34 Green MC. Catalog of mutant genes and polymorphic loci. In: Lyon MF, Searle AG, eds. Genetic variants and strains of the laboratory mouse, Oxford: Oxford University Press, 1989:241-4.

35 Hunt DM. Primary defect in copper transport underlies mottled mutants in the mouse. Nature 1974;249:852-4

36 Rowe DW, McGoodwin EB, Martin GR, Grahn D. Decreased lysyl oxidase activity in the aneurisme-prone, Decreased lysyl oxidase activity in the aneurism

37 Danks DM. Of mice and men, metals and mutations. $7 \mathrm{Med}$ Genet 1986;23:99-106.

38 Nielsen JT, Chapman VM. Electrophoretic variation for $\mathrm{X}$-chromosome-linked phosphoglycerate kinase (PGK-1) in the mouse. Genetics $1977 ; 87: 319-25$.

39 Levinson B, Vulpe C, Elder B, et al. The mottled gene is the mouse homologue of the Menkes disease gene. Nat Gene 1994;6:369-73.

40 Mercer JFB, Grimes A, Ambrosini L, et al. Mutations in the murine homologue of the Menkes gene in dappled and blotchy mice. Nat Genet 1994;6:374-8.

41 Das S, Levinson B, Vulpe C, Whitney S, Gitschier J, Packman S. Similar splicing mutations of the Menkes/mottled copper-transporting ATPase gene in occipital horn syndrome and the blotchy mouse. Am $\mathcal{f}$ Hum Genet 1995;56:570-6.
42 Westman JA, Richardson DC, Rennert OM, Morrow G. Atypical Menkes steely hair disease. Am f Med Genet 1988; 30:853-8.

43 Royce PM, Camakaris J, Danks DM. Reduced lysyl oxidase activity in skin fibroblasts from patients with Menkes' syndrome. Biochem f 1980;192:579-86.

44 Hämäläinen E-R, Jones TA, Sheer D, Taskinen $K$, Pihlajaniemi T, Kivirikko KI. Molecular cloning of human lysyl oxidase and assignment of the gene to chromosome 5q23.3-31.2. Genomics 1991;11:508-16.

45 Levinson B, Gitschier J, Vulpe C, Whitney S, Yang S, Packman S. Are X-linked cutis laxa and Menkes disease allelic? Nat Genet 1993;3:6

46 Kaler SG, Gallo LK, Proud VK, et al. Occipital horn syndrome and a mild Menkes phenotype associated with splice site mutations at the MNK locus. Nat Genet 1994;8 195-202.

47 Matsubara O, Tanaka H, Nasu M, Okeda R. An autopsy case of Menkes' kinky hair disease. Acta Pathol $\mathfrak{f p}_{p}$ 1978;28:585-94.

48 Iwakawa $\mathrm{Y}$, Niwa $\mathrm{T}$, Tomita $M$. Menkes' kinky hair syndrome: report of an autopsy case and his female sibling with similar clinical manifestations. Brain Dev (Tokyo) 1979;11:260-6.

49 Barton NW, Dambrosia JM, Barranger JA. Menkes' kinky-hair syndrome: report of a case in a female infant. Neurology 1983;33(suppl 2):154

50 Favier A, Boujet C. Possibility of Menkes-like disorder of copper metabolism in a girl. F Inherited Metabol Dis 1983;6(suppl 2):89.

51 Gerdes AM, Tønnesen T, Horn N, et al. Clinical expression of Menkes syndrome in females. Clin Genet 1990;38:452-9.

2 Beck J, Enders $\mathrm{H}$, Schliephacke M, Buchwald-Saal M, Tümer Z. X;1 translocation in a female Menkes patient: characterization by fluorescence in situ hybridization. Clin Genet 1994;46:295-8.

53 Rossiter BJF, Caskey CT. Molecular studies of human genetic disease. FASEB f 1991;5:21-7.

54 Tümer $Z$, Tønnesen $T$, Horn N. Detection of genetic defects in Menkes disease by direct mutation analysis and its implications in carrier diagnosis. F Inherited Metabol Dis 1994;17:267-70.

55 Das S, Levinson B, Whitney S, Vulpe C, Packman S, Gitschier J. Diverse mutations in patients with Menkes disease often lead to exon skipping. Am f Hum Genet 1994;55 883-9.

56 Tümer Z, Lund CL, Tolshave J, Tonnesen T, Horn N Identification of point mutations in 41 unrelated Menkes disease patients. Am 7 Hum Genet 1997;60:63-71.

57 Henkin RI, Schulman J, Schulman C. Changes in total nondiffusable and diffusable plasma zinc and copper during infancy. 7 Pediatr 1973;82:831-7.

58 Tonnesen T, Horn N. Prenatal and postnatal diagnosis of Menkes disease, an inherited disorder of copper metabolism. F Inherited Metabol Dis 1989;1(suppl 12):207-14

59 Horn N. Menkes' X-linked disease: prenatal diagnosis and carrier detection. F Inherited Metabol Dis 1983;1(suppl 6):59-62

60 Horn N. Copper incorporation studies on cultured cells for prenatal diagnosis of Menkes' disease. Lancet 1976;i:115660

61 Horn N. Menkes X-linked disease: prenatal diagnosis of hemizygous males and heterozygote females. Prenat Diagn 1981;1:107-20.

62 Horn N, Søndergaard F, Damsgaard E, Heydorn K. Prenatal diagnosis of Menkes disease by direct copper analysis of trophoblast tissue. In: Fraccaro M, Simoni G, Brambati B, eds. First trimester fetal diagnosis. Heidelberg: SpringerVerlag, 1985:251-5.

63 Tümer Z, Tønnesen T, Böhmann J, Marg W, Horn N. First trimester prenatal diagnosis of Menkes disease by DNA analysis. F Med Genet 1994;31:615-17.

64 Damsgaard E, Heydorn K. Trace elements in the placenta of normal foetuses and male foetuses with Menkes disease determined by neutron activation analysis. In: Brätter $P$ Schramel P, eds. Trace element-analytical chemistry in medicine and biology. Vol 2. Berlin: Walter de Gruyter, 1983 499-516.

65 Das S, Whitney S, Taylor J, et al. Prenatal diagnosis of Menkes disease by mutation analysis. $\mathcal{f}$ Inherited Metabol Dis 1995;18:364-5.

66 Horn N. Menkes X linked disease: heterozygous phenotype in uncloned fibroblast cultures. $\mathcal{F}$ Med Genet 1980;17:25761 .

67 Begy CR, Dierick H, Innis JW, Glover TW. Two highly polymorphic CA repeats in the Menkes gene $(A T P 7 A)$. Hum Genet 1995;96:355-6.

68 Kaler S. Menkes disease. Adv Pediatr 1994;41:263-304.

69 Sarkar B, Kruck TPA. Copper-amino acid complexes in human serum. In: Peisach J, Aisen P, Blumberg WE, eds The biochemistry of copper. New York: Academic Press, 1966:183-96

70 Sherwood G, Sarkar B, Sass Kortsak A. Copper histidinate therapy in Menkes' disease: prevention of progressive neurodegeneration. F Inherited Metabol Dis 1989;12(supp 2):393-6.

71 Sarkar B, Lingertat-Walsh K, Clarke JTR. Copper-histidine therapy for Menkes disease. F Pediatr 1993;123:828-30.

72 Nadal D, Baerlocher K. Menkes' disease: long term treatment with copper and D-penicillamine. Eur $\mathcal{F}$ Pediat 1988;147:621-5.

73 Danks D. Treatment from birth converts Menkes disease into occipital horn syndrome. VI International Congress of Inborn Errors of Metabolism, Milano, Italy, 1994:95. 
74 Williams DM, Atkin CL, Frens DB, Bray PF. Menkes' kinky hair syndrome: studies of copper metabolism and long term copper therapy. Pediatr Res 1977;11:823-6.

75 Kollros PR, Dick RD, Brewer GJ. Correction of cerebrospinal fluid copper in Menkes kinky hair disease. Pediatr Neurol 1991;7:305.

76 Kreuder J, Otten A, Fuder H, et al. Clinical and biochemical consequences of copper-histidine therapy in Menkes disease. Eur $\mathcal{F}$ Pediatr 1993;152:828-32.

77 Tümer Z, Horn N, Tønnesen T, Christodoulou J, Clarke JTR, Sarkar B. Efficacy of early copper-histidine treatment for Menkes disease. Nat Genet 1996;12:11-13.

78 Brewer GJ, Yuzbasiyan-Gurkan V. Wilson disease. Medicine 1992;71:139-64.

79 Yarze JC, Martin P, Muñoz SJ, Friedman LS. Wilson's disease: current status. $A m \mathcal{F}$ Med 1992;92:643-54.

80 Frydman M, Bonné-Tamir B, Farrer LA, et al. Assignment of the gene for Wilson disease to chromosome 13: linkage to the eserase D locus. Proc Natl Acad Sci USA 1985;82:1819-21.

81 Bowcock AM, Farrer LA, Cavalli-Sforza A, et al. Mapping the Wilson disease locus to a cluster of linked polymorphic markers on chromosome 13. Am ₹ Hum Genet 1987;41:2735.

82 Bowcock AM, Farrer LA, Hebert JM, et al. Eight closely linked loci place the Wilson disease locus within 13q14-21. Am f Hum Genet 1988;43:664-74.

83 Farrer LA, Bowcock AM, Hebert JM, et al. Predictive testing for Wilson's disease using tightly linked and flanking ing for Wilson's disease using tightly link

84 Bull PC, Thomas GR, Rommens JM, Forbes JR, Cox DW. The Wilson disease gene is a putative copper transporting
P-type ATPase similar to the Menkes gene. Nat Genet P-type ATPase

85 Yamaguchi Y, Heiny ME, Gitlin JD. Isolation and characterization of a human liver $\mathrm{CDNA}$ as a candidate gene for Wilson disease. Biochem Biophys Res Commun 1993;197:271-7.

86 Tanzi RE, Petrukhin K, Chernov I, et al. The Wilson disease gene is a copper transporting ATPase with homology to the Menkes disease gene. Nat Genet 1993;5:344-57.

87 Bull PC, Cox DW. Wilson disease and Menkes disease: new handles on heavy-metal transport. Trends Genet 1994;10: 246-52.

88 Petrukhin K, Lutsenko S, Chernov I, Ross BM, Kaplan JH, Gilliam TC. Characterization of the Wilson disease gene encoding a P-type copper transporting ATPase: genomic encoding a P-type copper transporting ATPase: genomic organization, alternative splicing, and structur
predictions. Hum Mol Genet 1994;3:1647-56.
89 Thomas GR, Forbes JR, Roberts EA, Walshe JM, Cox DW. The Wilson disease gene: spectrum of mutations and their consequences. Nat Genet 1995;9:210-17.

$90 \mathrm{Li} \mathrm{Y}$, Tagashi Y, Sato S, et al. Spontaneous hepatic copper accumulation in Long-Evans cinnamon rats with hereditary hepatitis: a model of Wilson's disease. F Clin Invest 1991;87:1858-61.

91 Wu J, Forbes JR, Chen HS, Cox DW. The LEC rat has a deletion in the copper transporting ATPase gene homologous to the Wilson disease gene. Nat Genet 1994;7:541-5.

92 Thomas GR, Roberts EA, Walshe JM, Cox DW. Haplotypes and mutations in Wilson disease. Am $f$ Hum Genet and mutations in

93 Thomas GR, Jensson O, Gudmundsson G, Thorsteinsson $\mathrm{L}$, Cox DW. Wilson disease in Iceland: a clinical and genetic study. Am $\mathcal{F}$ Hum Genet 1995;56:1 140-6.

4 Houwen RHJ, Juyn J, Hoogenraad TU, Ploos van Amstel $\mathrm{JK}$, Berger R. H714Q mutation in Wilson disease is associated with late, neurological presentation. $f$ Med Genet 1995;32:480-2.

95 Herd SM, Camakaris J, Christofferson R, Wookey P, Danks DM. Uptake and efflux of copper-64 in Menkes'-disease and normal continuous lymphoid cell lines. Biochem $f$ 1987;247:341-7.

96 Vulpe C, Packman S. Cellular copper transport. Annu Rev Nutr 1995;15:293-322.

97 Cox DW. Genes of the copper pathway. Am f Hum Genet 1995;56:828-34.

98 Lutsenko S, Genco M, Petrukhin K, Gilliam TC, Kaplan JH. Architecture of P-type ATPases: "core structure", spe-
cific domains, domain domain interactions. FASEB $\mathcal{F}$ cific domains,

99 Rad MR, Kirchrath L, Hollenberg CP. A putative P-type $\mathrm{Cu}^{2+}$-transporting ATPase gene on chromosome II of Saccharomyces cerevisiae. Yeast 1994;10:1217-25.

100 Fu D, Beeler TJ, Dunn TM. Sequence, mapping, and disruption of CCC2, a gene that cross-complements the $\mathrm{Ca}^{2+}$ sensitive phenotype of csgl mutants and encodes a P-type ATPase belonging to the $\mathrm{Cu}^{2+}$-ATPase subfamily. Yeast 1995;11:283-92.

101 Yuan DS, Stearman R, Dancis A, Dunn T, Beeler T, Klausner RD. The Menkes/Wilson disease gene homologue in yeast provides copper to a ceruloplasmin-like oxidase required for iron uptake. Proc Natl Acad Sci USA 1995;92:2632-6

102 Phung LT, Ajlani G, Haselkorn R. P-type ATPase from the cyanobacterium Synechococcus 7942 related to the human Menkes and Wilson disease gene products. Proc Natl Acad Sci USA 1994;91:9651-4.

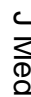

(1)

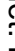

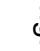

T

(

